\title{
Desmoid Tumor Treated with Polychemotherapy Followed by Imatinib: A Case Report and Review of the Literature
}

\author{
Gudrun Knechtel $^{\mathrm{a}}$ Herbert Stoeger $^{\mathrm{a}}$ Joanna Szkandera ${ }^{\mathrm{a}}$ \\ Katrin Dorr ${ }^{b}$ Alfred Beham ${ }^{c}$ Hellmut Samonigg ${ }^{a}$ \\ aDepartment of Internal Medicine, Division of Oncology, ${ }^{b} \mathrm{Clinic}$ of Therapeutic \\ Radiology and Oncology, and Institute of Pathology, Medical University Graz, \\ Graz, Austria
}

\section{Key Words}

Desmoid tumor · Aggressive fibromatosis · Chemotherapy · Imatinib

\begin{abstract}
Desmoid tumors, also known as aggressive fibromatosis, are tumors of intermediate dignity, which grow slowly but are locally aggressive. These tumors do not metastasize but can be potentially life threatening when infiltrating vital structures. The therapy strategy consists of surgery, radiation and systemic therapy with non-steroidal antiinflammatory drugs, antiestrogen compounds and cytotoxic chemotherapy. We report on a 40-year-old male patient with advanced fibromatosis of the neck who has been treated with 7 cycles of polychemotherapy (adriablastin, ifosfamide and dacarbazine) followed by targeted therapy with imatinib. Tumor response was evaluated clinically and by magnetic resonance imaging. The tumor decreased significantly after the first cycle of chemotherapy and tumor-related symptoms declined. The response continued after switching to targeted therapy with imatinib, which is currently ongoing. The best treatment for this rare tumor remains under discussion. Doxorubicin and dacarbazine are frequently used agents. We included ifosfamide in our therapy, which is standard in the treatment of soft tissue tumors. The tyrosine kinase inhibitor imatinib seems to offer new possibilities and is currently investigated in randomized trials. We conclude that combination chemotherapy including doxorubicin, ifosfamide and dacarbazine in the treatment of aggressive fibromatosis should be considered for patients suffering from unresectable, advanced disease and clinical symptoms which require a rapid response to therapy.
\end{abstract}




\begin{tabular}{|c|c|c|c|}
\hline $\begin{array}{c}\text { Case Reports in } \\
\text { Bnacaly }\end{array}$ & $\begin{array}{l}\text { Case Rep Oncol 2010;3:287-293 } \\
\text { D0I: } 10.1159 / 000318873\end{array}$ & Published online: August 6, 2010 & $\begin{array}{l}\text { @ } 2010 \text { S. Karger AG, Basel } \\
\text { ISSN 1662-6575 } \\
\text { www.karger.com/cro }\end{array}$ \\
\hline
\end{tabular}

\section{Introduction}

Desmoid tumors, also known as aggressive fibromatosis, are tumors of intermediate dignity according to the 2002 WHO classification [1]. These tumors grow slowly but are locally aggressive and can be potentially life threatening when infiltrating vital structures. Desmoids are very rare neoplasms with an incidence of 2-4 cases per 1 million inhabitants per year and make up about $5 \%$ of all soft tissue tumors [2]. The exact pathogenesis remains unclear; trauma and surgery as well as endocrine and genetic factors seem to be implicated in the development of desmoid tumors.

The therapy strategy for aggressive fibromatosis consists of local treatment with surgery and radiation $[3,4]$, systemic therapy with non-steroidal anti-inflammatory drugs (NSAIDs) [5], hormonal therapy [5] and chemotherapy [6-11, 14, 15].

Small extra-abdominal tumors are potentially curative when treated with surgery with wide local excision and histopathologic negative margins. The optimal treatment strategy for advanced, inoperable desmoid tumors consists of the use of NSAIDs [5], hormonal therapy with antiestrogen compounds or progesterone [5] and cytotoxic chemotherapy including ifosfamide, doxorubicin, dacarbazine, methotrexate and vinblastine [6-11, 14, 15]. Due to the rarity of the disease, no randomized trials are currently available comparing different chemotherapy regimens. The tyrosine kinase inhibitor imatinib shows promising results in first trials $[12,13]$.

We report on a patient with an advanced desmoid tumor on the right side of the neck who was successfully treated with polychemotherapy followed by a targeted therapy with imatinib.

\section{Methods}

In October 2007, a 40-year-old male patient presented with an advanced tumor involving the right and left supraclavicular area and the upper thorax. The tumor was ulcerated, fetid and continuously bleeding (fig. 1a) and the mobility of the neck and head was severely constricted. The patient needed constant oral analgesic therapy, and due to the tumor bleeding with severe anemia, continuing administration of blood transfusions was necessary.

The first occurrence of the lesion was 12 years ago. The patient noticed a solid painless tumor on the right side of the neck and underwent surgical excision. Histology revealed an aggressive fibromatosis. After tumor recurrence, no further operation or other local therapy was performed. Under systemic therapy with NSAIDs and 10 months of antiestrogen treatment with tamoxifen the tumor progressed.

After giving written informed consent, the patient was treated with polychemotherapy including ifosfamide, adriablastin and dacarbazine (IFADIC). He received $40 \mathrm{mg} / \mathrm{m}^{2}$ adriablastin on the first day and $1,500 \mathrm{mg} / \mathrm{m}^{2}$ ifosfamide and $200 \mathrm{mg} / \mathrm{m}^{2}$ dacarbazine daily for 4 days. After a febrile neutropenia, the dose of chemotherapy was consequently reduced to $75 \%$ and a granulocyte colony-stimulating factor (G-CSF) was given. No further neutropenia occurred with G-CSF support. Altogether, 7 cycles of polychemotherapy were administered according to the IFADIC-scheme. Due to a thrombosis of the right leg and the cumulative dose of adriablastin with regard to cardiotoxicity, the chemotherapy was discontinued.

To obtain the tumor response, we started a therapy with imatinib, a selective tyrosine kinase inhibitor, 2 months after the last cycle of chemotherapy. Since May 2008, the patient has been receiving $400 \mathrm{mg}$ of imatinib daily orally without any severe side effects.

Tumor response was evaluated clinically and by magnetic resonance imaging volumetry (MRI volumetry). MRI volumetry was performed using T2- and T1-weighted plain sequences after administration of gadolinium-diethylenetriaminepentaacetate. Tumor volume (in cubic centimeter, cc) was calculated by a slice-by-slice evaluation by the same radiologist. In addition, at each visit images of the tumor were taken to document the treatment response. 


\begin{tabular}{c|l|l|l}
$\begin{array}{c}\text { Case Reports in } \\
\text { Pntrity }\end{array}$ & $\begin{array}{l}\text { Case Rep Oncol 2010;3:287-293 } \\
\text { Dol: } 10.1159 / 000318873\end{array}$ & & $\begin{array}{l}\text { Published online: August 6, 2010 S. Karger AG, Basel } \\
\text { ISSN 1662-6575 } \\
\text { www.karger.com/cro }\end{array}$ \\
\hline
\end{tabular}

\section{Results}

After 2 cycles of chemotherapy, MRI showed an extensive tumor at the right upper thorax aperture with $20.5 \mathrm{~cm}$ craniocaudal $\times 17.5 \mathrm{~cm}$ transversal $\times 13.5 \mathrm{~cm}$ sagittal and a total tumor volume of $2,345.09 \mathrm{cc}$ (fig. 1d). Due to technical problems a comparison with the MRI before start of the therapy was not possible. The MRI volumetry after the fifth cycle confirmed the response $(1,898.76 \mathrm{cc})$, which was observed by clinical examination. At the end of chemotherapy, the desmoid tumor decreased to $1,078.78 \mathrm{cc}$ with a dramatically improvement of the clinical symptoms (fig. 1e).

During the targeted therapy, we observed a continuous reduction of the tumor. After 11 months the total volume was $931.47 \mathrm{cc}$. The last MRI volumetry was performed in July 2009 and showed a tumor volume of 7,445.26 cc (fig. 1f).

Clinical examination at each visit demonstrated a decrease of the tumor (fig. 1b, c) and clinical benefit with decline of tumor-related pain and an increased mobility in the neck.

\section{Discussion}

The role of chemotherapy in the treatment of advanced desmoid tumors is still under discussion. Due to the rarity of these lesions and the lack of clinical trials there is no standardized chemotherapy regime.

Janinis et al. [14] published a systematic review with overall response rates to combination chemotherapy from 17 to $100 \%$ using doxorubicin, dacarbazine, methotrexate and vinca alkaloids.

Methotrexate in combination with vinca alkaloids (vincristine and vinblastine) was used in different studies $[6,10,15]$. Azzarelli et al. [10] published a trial in which 30 patients with advanced aggressive fibromatosis responded to low-dose methotrexate and vinblastine weekly for a median of 1 year. Combination of methotrexate with vinorelbine is mentioned as an alternative with the same outcome but potentially slightly less neurotoxicity [15].

The most commonly used treatment regimes included the combination of doxorubicin and dacarbazine, which lead to responses in about $75 \%$ of the cases $[7-9,11]$. Common side effects of doxorubicin were acute and late cardiomyopathy and congestive heart failure. Patel et al. [8] reported death due to cardiomyopathy in a patient who received a cumulative dose of $1,000 \mathrm{mg} / \mathrm{m}^{2}$ doxorubicin for the treatment of aggressive fibromatosis.

Ifosfamide is a standard chemotherapy in the treatment of soft tissue sarcoma. Verrill et al. [16] showed chemosensitivity of fibromatosis cells to 4-hydroxy-ifosfamide (the active form of ifosfamide) in vitro. Successful treatment of 6 patients with the combination of ifosfamide and etoposide was reported by Okuno et al. [7].

Table 1 shows an overview of reported chemotherapeutic regimes in the treatment of desmoid tumors.

The tyrosine kinase inhibitor imatinib offers new possibilities in the treatment of aggressive fibromatosis. Imatinib is the standard first-line therapy for chronic myeloic leukemia and gastrointestinal stroma tumors. There are 2 prospective studies investigating imatinib for the treatment of aggressive fibromatosis [13, 14]. Preliminary 
data was presented at the American Society of Clinical Oncology annual meeting in 2006 and 2007 (table 2).

Altogether, the treatment of advanced aggressive fibromatosis remains difficult. The reported patient had a massive advanced tumor and a significant limitation of the quality of life. Constant analgesic therapy and blood transfusions were necessary. We decided to start combination chemotherapy with the intention to achieve a quick response and improve clinical symptoms. Based on the treatment of soft tissue tumors, we combined ifosfamide to doxorubicin and dacarbazine and the patient achieved a clinical benefit after the first cycle and clinical response was observed at every further clinical visit.

Although the desmoid tumor is cytological benign but locally aggressive and usually slowly growing, in some cases, an aggressive combination of chemotherapy is needed to obtain a quick response. Therefore the IFADIC-scheme could be a possible alternative for patients with advanced desmoids and clinical symptoms. Due to adequate supportive therapy side effects of chemotherapy are well manageable. As a limiting factor, the potential cardiotoxicity of doxorubicin must be mentioned.

\section{Conclusion}

The use of combination chemotherapy including doxorubicin, ifosfamide and dacarbazine in the treatment of aggressive fibromatosis should be considered for patients who suffer from unresectable, advanced disease. For stabilization of disease, further targeted therapy with imatinib presents a valid option. 
Table 1. Combination chemotherapy in the treatment of aggressive fibromatosis

\begin{tabular}{|c|c|c|c|c|c|}
\hline Study & $\begin{array}{l}\text { No. } \\
\text { pati }\end{array}$ & $\begin{array}{l}\text { Chemotherapeutic agents } \\
\text { ts }\end{array}$ & Response & $\begin{array}{l}\text { Duration } \\
\text { of therapy }\end{array}$ & $\begin{array}{l}\text { Follow- } \\
\text { up }\end{array}$ \\
\hline $\begin{array}{l}\text { Weiss and } \\
\text { Lackman } 1989 \\
\text { [6] }\end{array}$ & 8 & vinblastine and methotrexate & $\begin{array}{l}2 \mathrm{CR}, 5 \mathrm{PR} \\
1 \mathrm{MR}\end{array}$ & NR & NR \\
\hline $\begin{array}{l}\text { Okuno and } \\
\text { Edmonson } \\
2003 \text { [7] }\end{array}$ & 7 & $\begin{array}{l}\text { cyclophosphamide } 600 \mathrm{mg} / \mathrm{m}^{2} \text { and } \\
\text { doxorubicin } 60 \mathrm{mg} / \mathrm{m}^{2} ; \text { mitomycin } \\
8 \mathrm{mg} / \mathrm{m}^{2} \text {, doxorubicin } 40 \mathrm{mg} / \mathrm{m}^{2} \text {, and } \\
\text { cisplatin } 60 \mathrm{mg} / \mathrm{m}^{2} ; \text { ifosfamide } 2,500 \\
\mathrm{mg} / \mathrm{m}^{2} \text { and etoposide } 100 \mathrm{mg} / \mathrm{m}^{2}\end{array}$ & $\begin{array}{l}\text { Objective } \\
\text { disease } \\
\text { regression } \\
3 \text { patients, } \\
\text { clinical benefit } \\
6 \text { patients }\end{array}$ & $\begin{array}{l}3-12 \\
\text { months } \\
2-8 \text { cycles }\end{array}$ & $\begin{array}{l}3 \\
\text { months- } \\
15 \text { years }\end{array}$ \\
\hline $\begin{array}{l}\text { Patel et al. } \\
1993[8]\end{array}$ & 9 & $\begin{array}{l}\text { doxorubicin } 60-90 \mathrm{mg} / \mathrm{m}^{2} \text { and } \\
\text { dacarbazine } 750-1,000 \mathrm{mg} / \mathrm{m}^{2}\end{array}$ & $\begin{array}{l}2 \mathrm{CR}, 4 \mathrm{PR} \\
1 \mathrm{MR}, 2 \mathrm{SD}\end{array}$ & 5 cycles & $\begin{array}{l}28-253 \\
\text { months }\end{array}$ \\
\hline $\begin{array}{l}\text { Gega et al. } \\
2006[9]\end{array}$ & 7 & $\begin{array}{l}\text { doxorubicin } 20 \mathrm{mg} / \mathrm{m}^{2} \text { daily and } \\
\text { dacarbazine } 150 \mathrm{mg} / \mathrm{m}^{2} \text { followed by } \\
\text { meloxicam } 10 \mathrm{mg} / \mathrm{m}^{2}\end{array}$ & $3 \mathrm{CR}$ & 4 cycles & NR \\
\hline $\begin{array}{l}\text { Azzarelli et al. } \\
2001[10]\end{array}$ & 30 & $\begin{array}{l}\text { methotrexate } 30 \mathrm{mg} / \mathrm{m}^{2} \text { and } \\
\text { vinblastine } 6 \mathrm{mg} / \mathrm{m}^{2}\end{array}$ & $12 \mathrm{PR}, 18 \mathrm{SD}$ & 38 cycles & $\begin{array}{l}6-96 \\
\text { months }\end{array}$ \\
\hline $\begin{array}{l}\text { Tsukada et al. } \\
1991[11]\end{array}$ & 8 & $\begin{array}{l}\text { adriamycin } 50 \mathrm{mg} / \mathrm{m}^{2} \text { and } \\
\text { cyclophosphamide } 250 \mathrm{mg} / \mathrm{m}^{2} \text { and } \\
\text { vincristine } 2 \mathrm{mg} / \mathrm{m}^{2} \text { and } 5-\mathrm{FU} \\
275 \mathrm{mg} / \mathrm{m}^{2} ; \text { adriamycin } 50 \mathrm{mg} / \mathrm{m}^{2} \text { and } \\
\text { cyclophosphamide } 250 \mathrm{mg} / \mathrm{m}^{2} \text { and } \\
\text { dacarbazine } 250 \mathrm{mg} / \mathrm{m}^{2} \text { or actinomycin D }\end{array}$ & $2 \mathrm{CR}, 1 \mathrm{PR}$ & NR & NR \\
\hline $\begin{array}{l}\text { Weiss et al. } \\
1999[15]\end{array}$ & 17 & $\begin{array}{l}\text { methotrexate } 50 \mathrm{mg} \text { parenterally once a } \\
\text { week and vinorelbine } 20 \mathrm{mg} / \mathrm{m}^{2} \text { weekly }\end{array}$ & $\begin{array}{l}3 \mathrm{CR}, 7 \mathrm{PR} \\
2 \mathrm{MR}, 3 \mathrm{SD} \\
2 \mathrm{PD}\end{array}$ & NR & NR \\
\hline
\end{tabular}

Response evaluation according to Response Evaluation Criteria in Solid Tumours (RECIST): $\mathrm{CR}=$ complete response; $\mathrm{PR}=$ partial response; $\mathrm{SD}$ = stable disease; $\mathrm{MR}=$ minor response; $\mathrm{PD}=$ progressive disease; $\mathrm{NR}=$ not reported.

Table 2. Overview of studies investigating imatinib as treatment of desmoid tumors

\begin{tabular}{llll}
\hline Study & $\begin{array}{l}\text { No. of } \\
\text { patients }\end{array}$ & Dose of imatinib & Result \\
\hline $\begin{array}{l}\text { Chugh et al. } \\
\text { ASCO 2006 [12] }\end{array}$ & 51 & $2 \times 300 \mathrm{mg}$ daily & $\begin{array}{l}36 \text { patients had either CR, PR, (at } \\
2 \text { month) or SD (at 4 month) }\end{array}$ \\
\hline $\begin{array}{l}\text { Fayette et al. } \\
\text { ASCO 2007 [13] }\end{array}$ & 40 & $\begin{array}{l}400 \mathrm{mg} \text { daily, (increased } \\
\text { to } 800 \text { mg daily if } \\
\text { progression) for one year }\end{array}$ & $\begin{array}{l}\text { after 3 month: 1 CR, 3 PR, 31 SD, } \\
\text { after 13.8 month: 13 PD, } \\
1 \text { patient died }\end{array}$ \\
\hline
\end{tabular}

Response evaluation according to Response Evaluation Criteria in Solid Tumours (RECIST): $\mathrm{CR}=$ complete response; $\mathrm{PR}=$ partial response; $\mathrm{SD}=$ stable disease; $\mathrm{MR}=$ minor response; $\mathrm{NR}=$ not reported. 


\begin{tabular}{c|l|l|l}
$\begin{array}{c}\text { Cose Reports in } \\
\text { Onculagy }\end{array}$ & $\begin{array}{l}\text { Case Rep Oncol 2010;3:287-293 } \\
\text { D01: 10.1159/000318873 }\end{array}$ & Published online: August 6, 2010 & $\begin{array}{l}\text { O 2010 S. Karger AG, Basel } \\
\text { ISSN 1662-6575 } \\
\text { www.karger.com/cro }\end{array}$ \\
\hline
\end{tabular}

Fig. 1. Clinical presentation and MRI of the patient prior to the treatment (a, d), at the end of chemotherapy $(\mathbf{b}, \mathbf{e})$ and at the last visit after 18 months of imatinib $(\mathbf{c}, \mathbf{f})$.
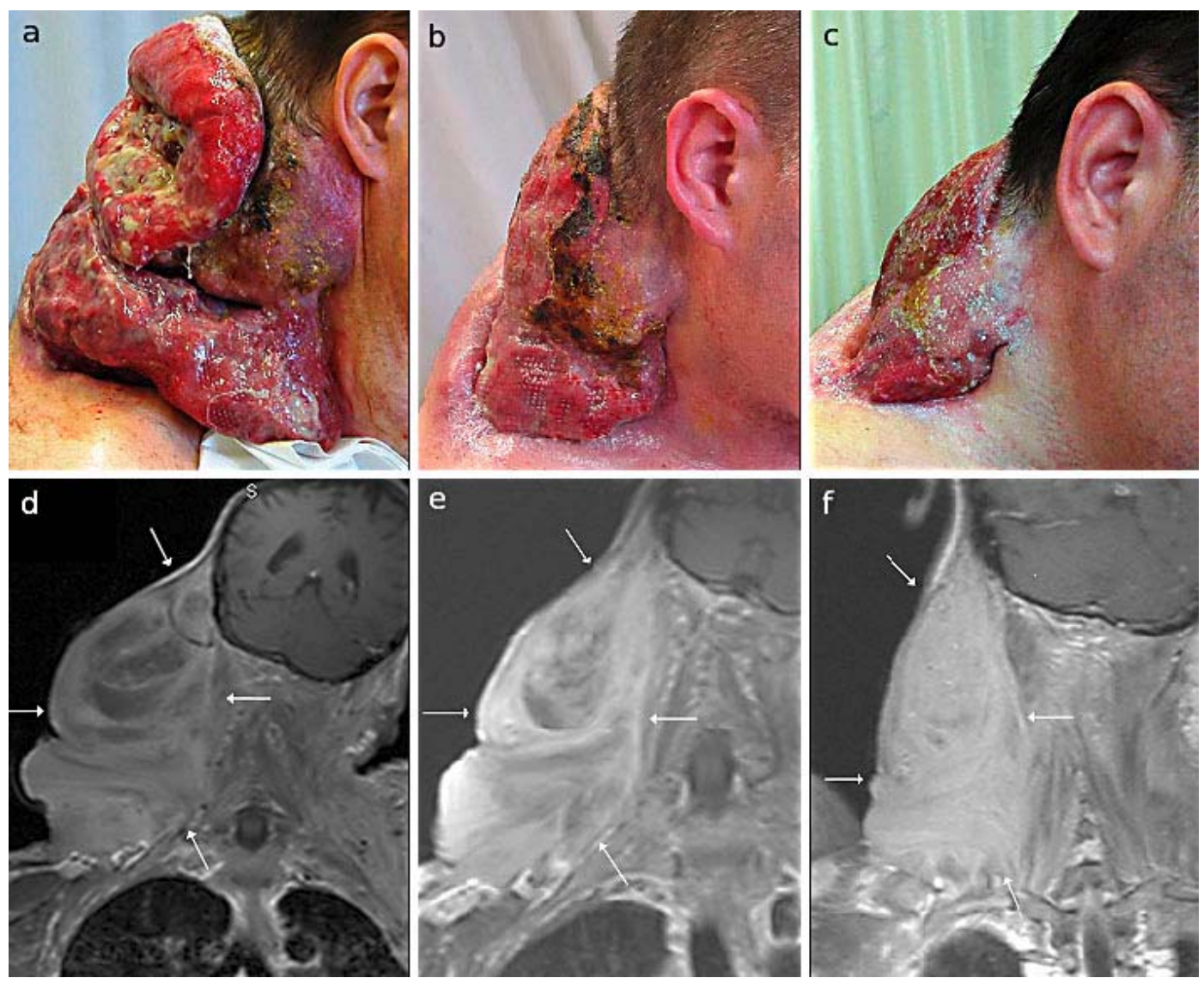


\begin{tabular}{|c|c|c|c|}
\hline $\begin{array}{l}\text { Case Reports in } \\
\text { Onatis }\end{array}$ & $\begin{array}{l}\text { Case Rep Oncol 2010;3:287-293 } \\
\text { D0I: 10.1159/000318873 }\end{array}$ & Published online: August 6, 2010 & $\begin{array}{l}\text { (c) } 2010 \text { S. Karger AG, Basel } \\
\text { ISSN } 1662-6575 \\
\text { www.karger.com/cro }\end{array}$ \\
\hline
\end{tabular}

\section{References}

1 Goldblum JR, Fletcher JA: Desmoid-type fibromatoses; in: Fletcher C, Krishnan Unni K, Mertens F (eds): World Health Organisation Classification of Tumours, Pathology \& Genetics, Tumours of Soft Tissue and Bone. Lyon, International Agency for Research on Cancer, 2002, pp 83-84.

2 Reitamo JJ, Scheinin TM, Häyry P: The desmoid syndrome. New aspects in the cause, pathogenesis and treatment of the desmoid tumor. Am J Surg 1986;151:230-237.

3 Zhu YX, Qian SZ, Zhang L, Wu Y, Ji QH: Treatment of desmoid tumour in head and neck. Zhonghua Er Bi Yan Hou Tou Jing Wai Ke Za Zhi (Chinese Journal of Otorhinolaryngology Head and Neck Surgery) 2008;43:432-434.

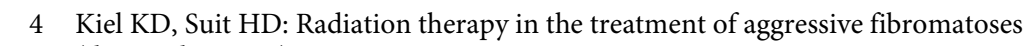
(desmoid tumors). Cancer 1984;54:2051-2055.

5 Waddell WR, Gerner RE, Reich MP: Nonsteroid antiinflammatory drugs and tamoxifen for desmoid tumors and carcinoma of the stomach. J Surg Oncol $1983 ; 22: 197-211$.

6 Weiss AJ, Lackman RD: Low-dose chemotherapy of desmoid tumors. Cancer 1989;64:1192-1194.

7 Okuno SH, Edmonson JH: Combination chemotherapy for desmoid tumors. Cancer 2003;97:1134-1135.

-8 Patel SR, Evans HL, Benjamin RS: Combination chemotherapy in adult desmoid tumors. Cancer 1993;72:3244-3247.

-9 Gega M, Yanagi H, Yoshikawa R, Noda M, Ikeuchi H, Tsukamoto K, Oshima T, Fujiwara Y, Gondo N, Tamura K, Utsunomiya J, Hashimoto-Tamaoki T, Yamamura T: Successful chemotherapeutic modality of doxorubicin plus dacarbazine for the treatment of desmoid tumors in association with familial adenomatous polyposis. J Clin Oncol 2006;24:102-105.

10 Azzarelli A, Gronchi A, Bertulli R, Tesoro JD, Baratti D, Pennacchioli E, Dileo P, Rasponi A, Ferrari A, Pilotti S, Casali PG: Low-dose chemotherapy with methotrexate and vinblastine for patients with advanced aggressive fibromatosis. Cancer 2001;92:1259-1264.

- 11 Tsukada K, Church JM, Jagelman DG, Fazio VW, Lavery IC: Systemic cytotoxic chemotherapy and radiation therapy for desmoid in familial adenomatous polyposis. Dis Colon Rectum 1991;34:1090-1092.

12 Chugh R, Maki RG, Thomas DG, Reinke D, Wathen JK, Patel S, Priebat DA, Meyers PA, Benjamin RS, Baker LH: A SARC phase II multicenter trial of imatinib mesylate (IM) in patients with aggressive fibromatosis. Annual Meeting Proceedings. J Clin Oncol ASCO 2006;24(18S):(Abstract 9515).

13 Fayette J, Dufresne A, Penel N, Le Cesne A, Bui Nguyen B, Tubiana-Hulin M, Guillemet C, Chabaud S, Jimenez M, Blay J: Imatinib for the treatment of aggressive fibromatosis/desmoid tumors (AF/DT) failing local treatment: updated outcome and predictive factors for progression free survivial. A FNCLCC French Sarcoma Group-GETO trial. Annual Meeting Proceedings. J Clin Oncol ASCO 2006;25(18S):(Abstract 1006).

14 Janinis J, Patriki M, Vini L, Aravantinos G, Whelan JS: The pharmacological treatment of aggressive fibromatosis: a systematic review. Ann Oncol 2003;14:8190.

15 Weiss AJ, Horowitz S, Lackman RD: Therapy of desmoid tumors and fibromatosis using vinorelbine. Am J Clin Oncol 1999;22:193-195.

16 Verrill MW, Coley HM, Judson IR, Fisher C: Susceptibility of fibromatosis cells in short-term culture to Ifosfamide: a possible experimental treatment in clinically aggressive cases. Sarcoma 1999;3:79-84. 